\title{
Ataksja u dzieci - jak rozpoznać i jak leczyć?
}

\section{Ataxia in children - how to diagnose and treat?}

\author{
Paulina Komasińska (D), Barbara Steinborn (iD) \\ Katedra i Klinika Neurologii Wieku Rozwojowego, Uniwersytet Medyczny im. K. Marcinkowskiego w Poznaniu \\ DOI:10.20966/chn.2019.57.446
}

\section{STRESZCZENIE}

Ataksja to zaburzenie koordynacji ruchowej ujawniające się podczas wykonywania ruchów celowych najczęściej poruszania i siedzenia. Wynika z uszkodzenia struktur móżdżku i jego połączeń lub sznurów tylnych rdzenia kręgowego. Na podstawie przebiegu klinicznego wyróżnia się ataksję ostrą - pojawia się nagle u najczęściej zdrowego dziecka, a jej objawy narastają dynamiczne. W większości przypadków ma łagodny, samoograniczający charakter, ale może również pojawić się w przebiegu procesów zagrażający życiu takich jak guz czy krwawienie w tylnym dole czaszki. W ataksjach nawracających związanych gtównie z wrodzonymi wadami metabolizmu, objawy ujawniają się pod wpływem czynników prowokujących takich jak: infekcja z gorączką, głodzenie, szczepienie. Ataksje przewlekłe stanowią heterogenną grupę chorób uwarunkowanych genetycznie lub wynikających z wad wrodzonych struktur tylnego dołu czaszki oraz będących konsekwencją encefalopatii niedotlenieniowo-niedokrwiennej, które mogą się ujawniać w różnym wieku i mieć charakter postępujący lub niepostępujący. W diagnostyce ataksji podstawowe znaczenie mają badania neuroobrazowe (rezonans magnetyczny gtowy i rdzenia kręgowego), a przy podejrzeniu chorób neurodegeneracyjnych i metabolicznych wykonanie badań genetycznych. Pomimo postępu jaki dokonał się w leczeniu niektórych zespołów chorobowych przebiegających $z$ ataksją $w$ ciągu ostatnich lat, poza nielicznymi wyjątkami, dla większości z nich terapią z wyboru pozostaje leczenie objawowe i wspomagające.

Słowa kluczowe: ostra ataksja móżdżkowa, ataksja czuciowa, ataksja nawracająca, ataksja przewlekła, zespół móżdżkowy
ABSTRACT

Ataxia is a disorder of motor coordination that manifests itself in performing purposeful movements, most often while moving and sitting. It results from damage to the cerebellar structures and its connections or to the posterior column pathway. Based on the clinical course there is distinguished acute ataxia with dynamically increasing symptoms appearing suddenly in a healthy child. In most cases it has a benign, self-limiting nature, but may also occur in life-threatening processes such as a tumor or bleeding in the back of the skull. In recurrent ataxia, associated mainly with congenital defects of the metabolism, the symptoms are manifested under the influence of provoking factors such as infection with fever, fasting, vaccination. Chronic ataxia is a heterogeneous group of diseases genetically determined or resulting from congenital malformations of the posterior cranial fossa structures, and, as a consequence of hypoxic-ischemic encephalopathy, it may appear at different ages and be progressive or non-progressive. In the diagnosis of ataxia, neuroimaging (magnetic resonance imaging of the head and spinal cord) is of fundamental importance, and when neurodegenerative and metabolic diseases are suspected, genetic testing is performed. Despite the progress that has been made in treating some ataxia disorders in recent years, with few exceptions, for most of patients the therapy of choice is symptomatic and supportive treatment.

Key words: acute cerebellar ataxia, sensory ataxia, recurrent ataxia, chronic ataxia, cerebellar syndrome

\section{WSTĘP}

Ataksja to upośledzenie koordynacji ruchowej oraz brak kontroli nad mięśniami szkieletowymi w trakcie wykonywania zamierzonych ruchów. Jeśli dotyczy kończyn może prowadzić do niestabilnego, wiążącego się z upadkami chodu, jeśli dotyczy tułowia jej konsekwencją są trudności w samodzielnym siedzeniu.

Ataksja jest związana z uszkodzeniem ośrodkowego układu nerwowego na różnych poziomach. Najczęściej wynika z defektu struktur móżdżku i/lub jego połączeń ze zwojami podstawy i korą mózgową. Ponadto może stanowić konsekwencję uszkodzenia nerwów obwodowych oraz dróg przewodzących czucie proprioceptywne jako tzw. ataksja czuciowa.

Ataksja nie stanowi częstego objawu w populacji pediatrycznej. W wieloośrodkowym, włoskim badaniu [1] spośród pacjentów w wieku 1-18 r.ż. zgłaszających się do pediatrycznej izby przyjęć ataksję zdiagnozowano zaledwie u 0,02\% (508) dzieci. W większości przypadków atak- sja miała charakter ostry, a jej przebieg był łagodny i samoograniczający. Jednak z uwagi na potencjalnie zagrażające życiu przyczyny takie jak: guz, krwawienie zlokalizowane w tylnym dole czaszki czy postępujący charakter w genetycznie uwarunkowanych chorobach neurodegeneracyjnych ujawnienie się ataksji w tej grupie wiekowej stanowi poważny problem kliniczny.

\section{KLASYFIKACJA ATAKSJI U DZIECI}

Pod względem przebiegu klinicznego ataksję u dzieci można sklasyfikować jako: ostrą, napadową, przewlekle niepostępującą, przewlekle postępującą. Ponadto z uwagi na lokalizację uszkodzenia ataksje można podzielić na móżdżkowe, czuciowe.

\section{MANIFESTACJE KLINICZNE ATAKSJI}

Prezentacja objawów klinicznych w zespole móżdżkowym wynika z lokalizacji uszkodzenia (robak versus półkule 
móżdżku) i wieku pacjenta. W grupie najmłodszych dzieci rozpoznanie ataksji jest trudne, może zostać mylnie zinterpretowana jako opóźnienie rozwoju koordynacji ruchowej.

Jeśli ognisko uszkodzenia zlokalizowane jest w półkulach móżdżku dzieci chodzą chwiejnie, na szerokiej podstawie, częściej upadają lub odmawiają chodzenia. Nie są w stanie stać ze złączonymi stopami czy przejść stopa za stopą wzdłuż linii prostej - zbaczają w stronę uszkodzonej półkuli móżdżku. Defekt w obrębie robaka móżdżku prowadzi natomiast do niestabilności tułowia (pacjent nie jest w stanie samodzielnie przyjąć pozycji siedzącej), wahadłowych ruchów głowy i tułowia - titubacji oraz oczopląsu.

Poza oczopląsem, w zespole móżdżkowym wyróżnia się także inne zaburzenia gałkoruchowe takie jak: nieprawidłowości dotyczące ruchów śledzących, występowania sakkad - ruchów skokowych gałek ocznych, trzepotania ocznego oraz opsoklonii.

Również mowa pacjentów w zespole móżdżkowym jest nieprawidłowa, niewyraźna, mało płynna. Pacjent dzieli słowa na sylaby, źle akcentuje głoski, zatrzymuje lub opuszcza pauzy. Napięcie mięśniowe jest obniżone, a w czasie wykonywania ruchów precyzyjnych obserwuje się drżenie zamiarowe, szarpnięcia i utratę płynności ruchów.

Dla ataksji czuciowej z kolei charakterystyczne są zaburzenia koordynacji kończyn nasilających się przy zamkniętych oczach, prowadzących podobnie jak ataksja móżdżkowa do nieprawidłowego, chwiejnego chodu. Dodatkowo stwierdza się nieprawidłowości w zakresie czucia dotyku, bólu, ciepła oraz czucia głębokiego, natomiast nie obserwuje się zaburzeń mowy, ani oczopląsu co stanowi cechę różnicującą z ataksją móżdżkową.

\section{ZESPOtY CHOROBOWE PRZEBIEGAJACE $Z$ OBJAWAMI ATAKSJI}

\section{Ataksje mózidzkowe o przebiegu ostrym}

Najczęstszy typ ataksji stanowi ostra ataksja móżdżkowa występująca głównie do 5 r.ż., stanowiąca 30-50\% przypadków ataksji u dzieci. Początek choroby jest nagły, objawy nasilają się w ciągu kilku godzin lub dni. Podstawowym odchyleniem $\mathrm{w}$ badaniu neurologicznym są zaburzenia chodu pod postacią opisaną powyżej, którym towarzyszą drżenia oraz w 50\% przypadków oczopląs. Mowa jest niewyraźna, niektórzy pacjenci mogą prezentować drażliwość, nudności i wymioty. Jej wystąpienie jest najczęściej poprzedzone infekcją z gorączką, rzadziej szczepieniem. Wiele potencjalnych czynników infekcyjnych jest zaangażowanych w patomechanizm tej choroby m. in.: wirusy z grupy Coxsackie, wirus Epsteina-Barr, zapalenia wątroby typu A, Parvowirus B19, ale również Mycoplasma pneumoniae i Borrelia burgdorferii. Klasyczny przykład stanowi ostra ataksja móżdżkowa w przebiegu zakażenia wirusem ospy wietrznej-półpaśca, która pojawia się najczęściej 2-6 dni od wystąpienia pierwszych wykwitów ospowych. Interesujący jest fakt, że ryzyko wystąpienia ostrej ataksji móżdżkowej po przebyciu choroby jest wyższe niż po szczepieniu przeciwko ospie wietrznej [2]. Ostra ataksja móżdżkowa wykazuje wiele cech wspólnych z ostrym zapaleniem móżdżku. Postuluje się udział tych samych czynników infekcyjnych, a różnica może doty- czyć cięższego przebiegu klinicznego i gorszego rokowania odległego w zapaleniu móżdżku. Według piśmiennictwa [3-5] w najcięższych przypadkach ostrego zapalenia móżdżku obserwowano objawy związane ze zwiększonym ciśnieniem wewnątrzczaszkowym wynikające z obrzęku móżdżku oraz ostrego wodogłowia, które nakładają się na objawy zaburzenia czynności móżdżku.

Ataksja może być wczesnym objawem zapalenia opon mózgowo-rdzeniowych lub konsekwencją formowania ropnia zlokalizowanego w móżdżku, powstającego jako powikłanie zapalenia ucha środkowego czy wyrostka sutkowatego. Wówczas przebiega zwykle z towarzyszącą gorączką oraz bólami głowy i wymiotami.

Wśród pozostałych przyczyn ataksji ostrej wyróżnia się toksyczne działanie leków (przeciwpadaczkowych, przeciwnowotworowych, immunosupresyjnych i benzodiazepin) oraz zatrucia m.in.: alkoholem, rtęcią, talem, litem, toluenem [1].

Do zagrażających życiu przyczyn ostrej ataksji móżdżkowej należą guzy, krwawienia w obrębie dołu tylnego czaszki. Większość guzów ośrodkowego układu nerwowego w populacji pediatrycznej lokalizuje się w pniu mózgu i móżdżku. Poza ataksją charakterystyczne są objawy wzrostu ciśnienia wewnątrzczaszkowego oraz porażenia nerwów czaszkowych. Choć w większości nowotworów zlokalizowanych w móżdżku ataksja ma charakter powoli postępujący, to narastające wodogłowie towarzyszące guzowi, obrzęk i krwawienie w jego obrębie zagrażają ostrą dekompensacją. Współwystępowanie ataksji oraz opsoklonii (szybkich, chaotycznych ,tańczących” ruchów gałek ocznych) oraz mioklonii obejmujących głowę, tułów i kończyny w ponad połowie przypadków pacjentów pediatrycznych jest związane z rozwojem nerwiaka zarodkowego (neuroblastomy) - drugiego pod względem częstości guza litego w tej populacji. Zespół Kinsbourne’a (zespół opsoklonii-mioklonii-ataksji) stanowi rzadką encefalopatię paranowotworową o charakterze immunologicznym, najczęściej występuje u dzieci 1.-4. r.ż, ale można go rozpoznać w grupie starszych nastolatków, a nawet u osób dorosłych, wówczas wiąże się z infekcjami lub nowotworami złośliwymi płuc, piersi. Objawy mogą się pojawiać w różnej kolejności, ze zmiennym nasileniem, w niektórych sytuacjach dyskretnie wyrażone opsoklonie i mioklonie nie pozwalają na odróżnienie zespołu od częściej występującej u dzieci ostrej ataksji móżdżkowej. Jednak w przeciwieństwie do ostrej ataksji móżdżkowej nieleczony zespół Kinsbourne'a prowadzi do poważnych i trwałych następstw behawioralnych i neurorozwojowych takich jak: opóźnienie rozwoju ruchowego i mowy, obniżenie zdolności poznawczych i zaburzenia zachowania [6].

Krwawienie do struktur tylnego dołu czaszki na skutek urazu lub malformacji naczyniowej przebiega z dynamicznie narastającą ataksją oraz znacznymi zaburzeniami świadomości. Należy zwrócić uwagę, że w niektórych przypadkach mechanizm urazu może zostać zatajony przez opiekunów, co ma miejsce w sytuacjach znęcania się nad dziećmi.

Ostra ataksja móżdżkowa może być wynikiem zaburzeń przepływu w tętnicach kręgowych oraz podstawnej, co wśród pacjentów pediatrycznych stanowi rzadkość 
i występuje głównie u dzieci z anemią sierpowatą, nadkrzepliwością (np. w przebiegu niektórych układowych chorób tkanki łącznej), homocystynurią.

Ataksja stanowi ponadto obok oftalmoplegii i arefleksji jeden spośród triady objawów w zespole Millera-Fishera, który jest odmianą zespołu Guillaina-Barrego [1].

Dyskusyjny pozostaje związek pomiędzy wystąpieniem ataksji a chorobami o podłożu immunologicznym. Jednym z przykładów jest ataksja glutenowa. Zaobserwowano, że podaż produktów zawierających gluten u dzieci, u których wykryto przeciwciała przeciw gliadynie, prowadziła do wystąpienia: chodu ataktycznego, oczopląsu, neuropatii obwodowej, a zastosowanie diety bezglutenowej powodowało ustąpienie powyższych objawów [7-8]. Do rozwoju ataksji mogą prowadzić również zaburzenia funkcjonowania tarczycy np. autoimmunizacyjne zapalenie tarczycy - choroba Hashimoto. W encefalopatii Hashimoto oprócz ataksji występują zaburzenia zachowania pod postacią napadów psychotycznych przebiegających z agresją, trudności w zapamiętywaniu, drżenia, mioklonie, a w najcięższych przypadkach śpiączka [9].

\section{Ataksje mózdikowe napadowe}

Drugą grupą ataksji, o której należy wspomnieć to ataksje napadowe. W zależności od etiologii można je podzielić na objawowe (metaboliczne) oraz idiopatyczne (uwarunkowane genetycznie). Specyficzną cechę napadowych ataksji o charakterze metabolicznym stanowi okresowe pojawianie się objawów, wyzwalane często przez infekcję, stres, głodzenie czy szczepienie. Do napadowych ataksji metabolicznych mogą prowadzić: choroba syropu klonowego, niedobór kompleksu dehydrogenazy pirogronianowej, choroba Hartnupów oraz niedobór biotynidazy.

Choroba syropu klonowego jest wynikiem niedoboru aktywności kompleksu enzymatycznego dehydrogenazy alfa-ketokwasów odpowiedzialnej za dekarboksylację aminokwasów o rozgałęzionych łańcuchach (Leucyny, Izoleucyny, Waliny). W stanie dekompensacji metabolicznej charakterystyczny jest słodki zapach moczu przypominający syrop klonowy, a pacjent oprócz ataksji prezentuje: nudności, wymioty, zaburzenia świadomości i halucynacje. Najcięższe przypadki powikłane są kwasicą metaboliczną, obrzękiem mózgu i zgonem.

Kompleks dehydrogenazy pirogronianu jest odpowiedzialny za konwersję pirogronianu do acetyloCoA. Deficyt aktywności enzymów wchodzących w skład kompleksu prowadzi do zaburzeń tlenowego spalania glukozy również w obrębie centralnego układu nerwowego, co skutkuje poza ataksją, globalnym zahamowaniem rozwoju, uogólnioną hipotonią, napadami padaczkowymi, bezdechami, postępującą encefalopatią.

Choroba Hartnupów będąca zaburzeniem transportu obojętnych aminokwasów w świetle jelita i kanalików nerkowych oprócz nieprawidłowości w postaci chodu na szerokiej podstawie, prowadzi do nadwrażliwości skóry na światło słoneczne objawiającej się występowaniem zaczerwienia i osutki z bardzo nasilonym świądem.

Niedobór biotynidazy to zaburzenie metaboliczne związane $\mathrm{z}$ deficytem biotynidazy (enzymu uwalniają- cego biotynę $\mathrm{z}$ kompleksu biocytyny), które wiąże się $\mathrm{z}$ brakiem działania biotyny-witaminy zaangażowanej w procesy metabolizmu białek, tłuszczów, syntezę kwasów tłuszczowych oraz zapewniającej odpowiednie funkcjonowanie skóry, włosów i paznokci. Jej niedobór skutkuje ataksją chodu, opóźnieniem rozwoju psychoruchowego, niedowładami kończyn, napadami drgawek (często lekoopornych), hipotonią, zanikiem nerwów wzrokowych oraz nadmiernym wypadaniem włosów, zmianami o charakterze łuszczycowym oraz przebarwieniem skóry i błon śluzowych. Najczęściej pierwsze objawy pojawiają się w okresie niemowlęcym, jednak wiek ich ujawnienia jest skorelowany ze stopniem niedoboru aktywności enzymu (głęboki< 10\%, częściowy 10-30\%).

Oprócz ataksji związanych $\mathrm{z}$ wadami metabolizmu do grupy ataksji napadowych zalicza się również uwarunkowane genetycznie (sposób dziedziczenia autosomalnie dominujący) choroby tzw. ataksje epizodyczne. Do tej pory na podstawie charakterystyki klinicznej i genetycznej wyróżniono 8 ich podtypów. W artykule zostaną omówione 2 najczęstsze. Napadowa ataksja typu I związana jest z mutacją genu kodującego podjednostkę kanału potasowego (KCNA1). Charakterystyczną jej cechą jest występowanie w dzieciństwie epizodów zawrotów i bólów głowy z wymiotami, którym towarzyszy dyzartria i chwiejny chód. Liczba incydentów waha się od jednego do kilku dziennie, trwają od kilku sekund do kilku minut. W okresie międzynapadowym stwierdza się u pacjenta miokimie (mimowolne skurcze pojedynczych włókien lub grup mięśniowych widoczne, ale nie powodujące ruchu) w obrębie twarzy i kończyn.

Napadowa ataksja typu II to choroba również należąca do kanałopatii, spowodowana mutacją genu $C A C N A 1 A$ (kodującego kanał wapniowy), której objawy pojawiają się najczęściej w dzieciństwie lub okresie młodzieńczym. W czasie napadu pacjent prezentuje: zawroty głowy, nudności, wymioty, porażenie ruchów gałek ocznych, oczopląs, dystonie. Epizody trwają od kilku godzin do kilku dni. Większość pacjentów pomiędzy napadami jest bezobjawowa, ale z czasem oczopląs i ataksję można obserwować również $\mathrm{w}$ okresie międzynapadowym. Incydenty są prowokowane przez wiele różnych czynników w tym: alkohol, kofeinę, stres, wysiłek fizyczny i fenytoinę.

Ataksja może również stanowić jeden z objawów napadu migreny podstawnej, w którym dodatkowo występują zaburzenia widzenia, dyzartria, zawroty i ból głowy przy obciążonym wywiadzie rodzinnym [10].

\section{Ataksje móidizowe o przebiegu przewlekłym}

W odróżnieniu od ataksji ostrych, ataksje przewlekłe stanowią u dzieci rzadkość. Do grupy tej włącza się wiele chorób wrodzonych, dziedzicznych, ujawniających się w różnym wieku, manifestujących się szerokim spektrum współwystępujących objawów dodatkowych.

Ataksje przewlekłe mogą mieć charakter postępujący lub niepostępujący. Do ataksji o niepostępującym charakterze zalicza się wady wrodzone móżdżku takie jak: hipoplazja móżdżku, aplazja robaka, zespół Joubert, malformacja Arnolda-Chiariego i zespół Dandy’ego-Walkera oraz 
zaburzenia będące następstwem encefalopatii niedotlenieniowo-niedokrwiennej.

Malformacja Arnolda-Chiariego stanowi zaburzenie rozwoju cewy nerwowej, polega na przemieszczeniu struktur tylnego dołu czaszki poniżej otworu wielkiego do kanału kręgowego. Dla typu pierwszego charakterystyczne jest przemieszczenie migdałków móżdżku, w typie drugim dochodzi do przemieszczenia dolnej części robaka móżdżku, pnia mózgu, a w trzecim całego móżdżku poniżej otworu wielkiego. Typ czwarty natomiast odróżnia się od pozostałych-poza przemieszczeniem móżdżku wiąże się z niedorozwojem jego struktur. W typie pierwszym najczęstsze objawy to bóle głowy w okolicy potylicznej i bóle karku nasilające się podczas próby Valsalvy, dodatkowo ucisk migdałków móżdżku na pień mózgu, rdzeń kręgowy może prowadzić do dyzartrii, dysfagii, zaburzeń oddychania. Częstym znaleziskiem w tym typie malformacji jest syringomelia (jamistość) rdzenia kręgowego. W typie drugim bardzo często stwierdza się współtowarzyszące wady rdzenia i kanału kręgowego - przepuklinę oponowo-rdzeniową oraz wady mózgowia - wodogłowie, polimikrogyrię, zwężenie wodociągu.

W zespole Dandy'ego-Walkera dochodzi do zaburzeń rozwoju robaka móżdżku o charakterze hipoplazji, poszerzenia komory IV, rozwoju torbieli w tylnej jamie czaszki. W 80\% przypadków stwierdza się wodogłowie. Zespół ten może występować jako izolowany lub współwystępować $\mathrm{z}$ innymi wadami ośrodkowego układu nerwowego, serca, układu kostnego czy moczowego. Do podstawowych problemów zdrowotnych pacjentów z tym zespołem, poza ataksją należą: opóźniony rozwój psychoruchowy, nadmierny przyrost obwodu głowy oraz objawy wzmożonego ciśnienia wewnątrzczaszkowego będące konsekwencją narastającego wodogłowia [10].

Zespół Joubert jest uwarunkowaną genetycznie o autosomalnie recesywnym sposobie dziedziczenia (zidentyfikowano 20 genów związanych z tym zespołem) hipoplazją mostowo-móżdżkową. Wady strukturalne w tym zespole obejmują m.in.: zmniejszenie liczby komórek w obrębie robaka móżdżku, zwyrodnienie i zanik jąder mostu, fragmentację jądra zębatego. U chorych występuje opóźnienie rozwoju psychoruchowego, hipotonia mięśniowa, ruchowa apraksja oczna, zaburzenia oddychania (bezdech i hiperwentylacja), dystrofia siatkówki, torbielowatość nerek, wrodzone zwłóknienie wątroby, polidaktylia. W badaniu rezonansu magnetycznego charakterystyczną cechą jest tzw. objaw zęba trzonowego wynikający z wydłużenia konarów górnych móżdżku i głębokiego dołu międzykonarowego przypominającego kształtem ząb trzonowy [10].

Wśród ataksji przewlekłych wyróżniamy również ataksje o charakterze postępującym, które stanowią heterogenną klinicznie grupę zaburzeń neurodegeneracyjnych. Najlepiej poznano dziedziczone autosomalnie recesywnie ataksje móżdżkowe (autosomal recessive cerebellar ataxia - ARCA) i ataksje rdzeniowo-móżdżkowe (spino-cerebellar ataxia - SCA).

Do najczęstszych ARCA należą: ataksja Friedreicha oraz zespół ataksja - teleangiektazja.

Ataksja Friedreicha to choroba wywołana mutacją dynamiczną (wynikającą ze zwiększenia liczby powtórzeń
GAA > 66) w genie $F X N$ kodującym białko frataksynę. Kluczowym objawem jest postępująca ataksja kończyn początkowo dolnych następnie górnych i dołączająca się z czasem ataksja tułowia. Patomechanizm ataksji w tym zespole wynika $\mathrm{z}$ asynergii móżdżkowej oraz zaburzeń czucia proprioceptywnego. Dodatkowo występują: dyzartria, dysfagia oraz zaburzenia gałkoruchowe. W badaniu neurologicznym z odchyleń stwierdza się: brak odruchów ścięgnistych w obrębie kończyn dolnych, obecny objaw Babińskiego, stopę o kształcie wydrążonym z bagnetowato ustawionym paluchem. W miarę postępu choroby dochodzi do rozwoju kardiomiopatii przerostowej i zaburzeń rytmu serca, cukrzycy, skoliozy. U większości pacjentów objawy ujawniają się pomiędzy 8. a 15. r.ż. Postępujący charakter schorzenia prowadzi do utraty samodzielnego poruszania, średnio po 15 latach trwania choroby, choć zakres ten jest szeroki i wynosi od 3 do 44 lat.

Zbliżony do ataksji Friedreicha obraz kliniczny występuje w izolowanym niedoborze witaminy $\mathrm{E}$ i abetalipoproteinemii.

Do manifestacji klinicznych izolowanego niedoboru witaminy $\mathrm{E}$, który wynika $\mathrm{z}$ mutacji genu kodującego białko transportujące witaminę E, poza powoli postępującą ataksją, należą: polineuropatia, drżenia głowy, zwyrodnienie barwnikowe siatkówki i skolioza. Pierwsze objawy pojawiają się najczęściej pomiędzy 5. a 20. r.ż, a pomiędzy 11. a 50. r.ż dochodzi do utraty zdolności samodzielnego poruszania się.

Obniżone stężenie witaminy E może być również wynikiem zaburzeń wchłaniania $\mathrm{z}$ przewodu pokarmowego tłuszczów, które mają miejsce w abetalipoproteinemii.

Abetalipoproteinemia (zespół Bassena-Kornzweiga) to autosomalnie recesywnie dziedziczona choroba, związana z defektem tworzenia i wydzielania apolipoprotein wiążących i transportujących tłuszcze, w której podstawowymi objawami są: postępująca ataksja chodu, polineuropatia czuciowo-ruchowa, zaburzenia czucia głębokiego, zwyrodnienie barwnikowe siatkówki. Towarzyszą im przewlekłe biegunki tłuszczowe oraz utrata masy ciała [10-11].

Zespół ataksja-teleangiektazja (zespół Louis-Bar) stanowi wieloukładową, postępującą chorobę, uwarunkowaną mutacjami genu ATM (kodującego kinazę ATM biorącą udział w naprawie uszkodzeń w DNA oraz kontroli apoptozy), której główny objaw - ataksja tułowia pojawia się we wczesnym dzieciństwie (pomiędzy 18. m.ż a 5. r.ż) w znacznym stopniu zaburza siadanie i samodzielne chodzenie. Charakterystyczne poszerzone naczynia (teleangiektazje) są najlepiej widoczne pomiędzy 3. a 6. r.ż w obrębie spojówek, małżowin usznych i fałdów zgięciowych skóry. W późniejszym wieku może się dołączyć: dystonia, pląsawica, mioklonie, neuropatia czuciowa. Problem o dużym znaczeniu klinicznym stanowią nawracające infekcje dróg oddechowych i skóry (jako konsekwencja zaburzonej odporności humoralnej i komórkowej) oraz istotnie podwyższone ryzyko rozwoju nowotworów układu krwiotwórczego - białaczek, chłoniaków oraz nerwowego rdzeniaków i glejaków. Większość pacjentów do wieku nastoletniego traci umiejętność samodzielnego chodzenia, ubierania i jedzenia [10-11]. 
Ataksje rdzeniowo-móżdżkowe (SCA) to grupa ponad 30 zaburzeń dziedziczonych w sposób autosomalnie dominujący. Niektóre z nich są spowodowane zwiększeniem liczby powtórzeń sekwencji CAG kodującej glutaminę - SCA 1-3, 6, 7, 17, inne wiążą się ze zwiększoną liczbą powtórzeń sekwencji niekodujących - SCA 8, 10, 12, 31, 36. Pozostałe wynikają z mutacji punktowych. Choć objawy w większości typów SCA ujawniają się w wieku dorosłym, to znane są również przypadki zachorowania dzieci, a nawet niemowląt (SCA 1, 2, 3, 7). Postępującemu zespołowi móżdżkowemu towarzyszą objawy pozapiramidowe, piramidowe, neuropatia obwodowa, zaburzenia poznawcze i padaczka. W niektórych stwierdza się choroby siatkówki prowadzące do utraty wzroku. W wielu przypadkach na właściwe rozpoznanie naprowadza dodatni wywiad rodzinny [11].

Ataksja może stanowić jeden $\mathrm{z}$ wielu objawów chorób mitochondrialnych takich jak: neurogenna miopatia $\mathrm{z}$ ataksją i zwyrodnieniem barwnikowym siatkówki oraz padaczka miokloniczna z włóknami szmatowatymi. Choroby te mogą być wynikiem mutacji w genomie jądrowym (kodującym białka regulacyjne i strukturalne mitochondrium) oraz mitochondrialnym odpowiedzialnym za dziedziczenie odmatczyne. Schorzenia o tym typie dziedziczenia należy podejrzewać w przypadku wystąpienia objawów klinicznych ze strony narządów o najbardziej aktywnym metabolizmie energetycznym - ośrodkowego układu nerwowego, mięśni, serca.

Poza dziedziczeniem autosomalnym recesywnym, dominującym i mitochondrialnym, dziedziczenie chorób, w przebiegu których występuje ataksja może być sprzężone z chromosomem X. Choroby o tym typie dziedziczenia generalnie częściej ujawniają się u mężczyzn, poza nielicznymi wyjątkami (zespół Retta), w których chorują kobiety. Choć objawy móżdżkowe mogą występować samodzielnie, częściej towarzyszą im: spastyczność, głuchota, niepełnosprawność intelektualna, zaburzenia widzenia (np. zespół ataksji z drżeniem, zespół Artsa, zespół niepełnosprawności intelektualnej z padaczką i ataksją).

Wspomniany powyżej zespół Retta wywołany jest mutacją w genie $M E C P 2$ zlokalizowanym na chromosomie $\mathrm{X}$ (Xq28). Charakteryzuje się zahamowaniem i regresem rozwoju psychoruchowego, do którego dochodzi po 6-18 miesiącach prawidłowego funkcjonowania dziecka, z czasem dołącza się utrata celowego posługiwania się dłońmi oraz umiejętności mowy i chodzenia. Następnie w obrazie klinicznym pojawiają się ruchy stereotypowe, napady padaczkowe, zachowania autystyczne.

Ataksja przewlekle postępująca wpisuje się ponadto w spektrum objawów klinicznych chorób neurometabolicznych takich jak: cereidolipofuscynozy, choroba Niemanna-Picka typ C, gangliozydoza GM2, niedobór transportera glukozy typu 1, choroba Refsuma, ksantomatoza mózgowo-ścięgnista.

Cereidolipofuscynozy to różnorodna grupa chorób, których cechę wspólną stanowi wewnątrzlizosomalne spichrzanie lipofuscyny. Dla najczęstszej postaci-późnoniemowlęcej związanej z deficytem peptydylotripeptydazy charakterystyczne jest występowanie ataksji, drgawek, regres $\mathrm{w}$ rozwoju oraz utrata wzroku.
Choroba Niemanna-Picka typ C wynika z defektu transportu wewnątrzkomórkowego wolnego cholesterolu co prowadzi do spichrzania sfingolipidów i glikosfingolipidów. Obraz kliniczny tej choroby jest bardzo zróżnicowany klinicznie. Objawy mogą się pojawiać już w okresie płodowym (uogólniony obrzęk płodu), niemowlęcym (hipotonia, opóźnienie rozwoju psychoruchowego) lub w wieku późniejszym (ataksja, dyzartria, dystonia, dyspraksja, dysfagia, katapleksja, oftalmoplegia nadjądrowa, zaburzenia psychiatryczne).

Gangliozydoza GM2 spowodowana jest deficytem heksozaminidazy A (choroba Taya-Sachsa) lub heksozaminidazy A i B ( choroba Sandhoffa). Również w tych chorobach obraz kliniczny jest zróżnicowany i zależny od wieku. W postaci niemowlęcej występuje makrocefalia, opóźnienie rozwoju psychoruchowego, nadwrażliwość na bodźce zewnętrzne, w postaci dziecięcej dodatkowo mioklonie i ataksja, a w postaci dorosłych zaburzenia psychiatryczne.

Niedobór transportera GLUT 1 (głównie dziedziczony autosomalnie dominująco, rzadziej recesywnie) związany jest ze zmniejszonym transportem glukozy z krwioobiegu do ośrodkowego układu nerwowego. Spektrum objawów klinicznych jest bardzo złożone, obejmuje: napady padaczkowe o semiologii napadów nieświadomości, miokloniczno-astatycznych oraz niepadaczkowe zaburzenia ruchowe takie jak: ataksja, choreatetoza, dystonia czy porażenie naprzemienne. Specyficzny jest wczesny początek napadów padaczkowych, najczęściej poniżej 2 r.ż oraz opóźnienie rozwoju psychoruchowego, z następczą niepełnosprawnością intelektualną w stopniu znacznym. Zaburzenia ruchowe mogą występować stale lub okresowo zaostrzać się pod wpływem czynników prowokujących takich jak: ćwiczenia fizyczne czy głodzenie [11-12].

Choroba Refsuma stanowi rzadkie zaburzenie metaboliczne kwasu fitanowego z postępującymi objawami, które ujawniają się najczęściej w wieku wczesnoszkolnym. Do charakterystycznych objawów należą: ataksja móżdżkowa, neuropatia obwodowa (czuciowo-ruchowa dotycząca początkowo kończyn dolnych), zwyrodnienie barwnikowe siatkówki (ślepota nocna, zawężenie pola widzenia) oraz podwyższony poziom białka w płynie mózgowo-rdzeniowym. Rzadziej obserwuje się zaburzenia słuchu, anosmię oraz zmiany skórne pod postacią „rybiej łuski” i zniekształcenia kostne stóp - skrócenie czwartej kości śródstopia.

Ksantomatoza mózgowo-ścięgnista (zespół Van Bogaerta-Scherera-Epsteina) to choroba dziedziczona w sposób autosomalnie recesywny, wynikająca $\mathrm{z}$ niedoboru 27-hydroksylazy sterolu, który skutkuje akumulacją cholestanolu. Do jej głównych objawów należą: pogorszenie wyników szkolnych, zaburzenia osobowości, zespół móżdżkowy, zespół piramidowy, obwodowa polineuropatia ze zniesieniem odruchów głębokich oraz z zaburzeniami czucia wibracji, żółtaki ścięgien i zaćma.

\section{Ataksja czuciowa}

Odrębną grupę stanowią jednostki chorobowe, w których dominujący objawem jest ataksja czuciowa. 
Ataksja czuciowa może wynikać z niedoboru witaminy B12, stosowania chemioterapeutyków, substancji toksycznych, czy zakażenia wirusami: HIV, HCV, HTLV. Ponadto może wystąpić w przebiegu: stwardnienia rozsianego, cukrzycy oraz omawianych powyżej ataksji dziedzicznych móżdżkowych tj. ataksji Friedreicha, ataksji z niedoboru witaminy E, abetalipoproteinemii oraz w ataksji rdzeniowo-móżdżkowej z neuropatią (SCAN 1) [13].

\section{DIAGNOSTYKA ATAKSJI}

Diagnostyka ataksji w populacji pediatrycznej stanowi złożone zagadnienie. Wybór najbardziej optymalnych narzędzi diagnostycznych jest uzależniony w głównej mierze od wywiadu, wyników badania neurologicznego i pediatrycznego. Informacje dotyczące wieku, w którym pojawiły się objawy, tempa ich narastania oraz współwystępowania dodatkowych symptomów pozwalają podjąć decyzję. Obecność teleangiektazji (poszerzonych naczyń) zlokalizowanych w obrębie skóry, spojówek pozwala myśleć o zespole ataksja-teleangiektazja. Jeśli natomiast w badaniu przedmiotowym stwierdzono deformacje stóp, kręgosłupa można wysunąć podejrzenie ataksji Friedreicha. Powiększenie wątroby i śledziony wiąże się z chorobą Niemanna-Picka typu C, a zmiany skórne i łysienie z niedoborem biotynidazy i chorobą Hartnupów. Opsoklonie i mioklonie mogą być manifestacją zespołu Kinsbourne’a, którego przyczyną jest guz złośliwy - neuroblastoma.

Bez względu na współtowarzyszące objawy każdy pacjent $\mathrm{z}$ ataksją powinien mieć wykonane badanie neuroobrazowe. Takie postępowanie jest szczególnie wskazane jeśli towarzyszą jej zaburzenia świadomości, asymetryczne osłabienie siły mięśniowej, ból głowy nasilający się w czasie leżenia, z poprawą po wymiotach, podejrzewa się uraz. Badaniem z wyboru pozostaje rezonans magnetyczny (MR) głowy i rdzenia kręgowego. W najczęstszej postaci - ostrej ataksji móżdżkowej nie stwierdza się odchyleń lub uwidacznia się rozsiane, niepatognomiczne zmiany w obu półkulach móżdżku bez istotnej wartości prognostycznej. W zapaleniu móżdżku poza osłabieniem sygnału w badaniu MR, można uwidocznić jego obrzęk lub towarzyszące wodogłowie. Często obserwowaną nieprawidłowością jest zanik móżdżku - w uszkodzeniu toksycznym, chorobach o podłożu autoimmunologicznym, niedoczynności tarczycy, w zespole ataksja-teleangiektazja, w ataksji z apraksją gałkoruchową, w ataksji rdzeniowo-móżdżkowej 5, 6, gangliozydozie GM 2. Jeśli zanikowi móżdżku towarzyszą zmiany w istocie białej może to świadczyć o cereidolipofuscynozie, chorobie Niemanna-Picka typ C, leukodystrofiach. Natomiast gdy stwierdza się dodatkowo zanik w obrębie rdzenia kręgowego należy myśleć o ataksji Friedreicha i izolowanym niedobrze witaminy $\mathrm{E}$.

Poza MR głowy przy podejrzeniu tła infekcyjnego lub autoimmunologicznego objawów móżdżkowych, oraz braku przeciwskazań należy wykonać punkcję lędźwiową.

W ostrej ataksji móżdżkowej i zapaleniu móżdżku można stwierdzić w badaniu płynu mózgowo-rdzeniowego niespecyficzne odchylenia w postaci pleocytozy i podwyższonego stężenia białka, w niedoborze transportera GLUT 1 obniżone stężenie glukozy, a w zespole Millera-Fishera wystąpienie tzw. rozszczepienia białkowo-komórkowego (wysokie stężenie białka przy prawidłowej lub nieznacznie zwiększonej liczbie leukocytów).

Ważną rolę w procesie diagnostycznym odgrywa wykonanie testów laboratoryjnych, które może przyśpieszyć i ułatwić postawienie rozpoznania przed skierowaniem pacjenta na bardziej szczegółowe badania dodatkowe.

$\mathrm{W}$ ataksji o ostrym początku w pierwszej kolejności należy rozważyć wykonanie badań toksykologicznych (z krwi i moczu) oraz oznaczenie poziomów leków, które pacjent przyjmuje przewlekle. W grupie dzieci $\mathrm{z}$ ataksją epizodyczną wskazane jest przeprowadzenie diagnostyki metabolicznej, szczególnie jeśli towarzyszą jej wymioty, zaburzenia świadomości, powiększenie narządów miąższowych jamy brzusznej. W ramach diagnostyki metabolicznej należy wykonać ocenę: parametrów wątrobowych, gospodarki kwasowo-zasadowej, stężenia glukozy, poziomu mleczanów, pirogronianu, amoniaku, aminogram, profil kwasów organicznych w moczu oznaczenie aktywności biotynidazy w osoczu lub suchej kropli krwi (niedobór biotynidazy).

W diagnostyce ataksji przewlekłych pomocne może być wykonanie oznaczenia stężenia alfa - fetoproteiny, które jest podwyższone w zespole ataksja-teleangiektazja oraz w zespole ataksja $\mathrm{z}$ apraksją gałkoruchową typu II. $\mathrm{W}$ ataksji przebiegającej $\mathrm{z}$ izolowanym niedoborem witaminy $\mathrm{E}$ i abetalipoproteinemii stężenie witaminy $\mathrm{E}$ jest obniżone. Ponadto w abetalipoproteinemii występuje niedobór pozostałych witamin rozpuszczalnych w tłuszczach: A,D,K oraz hipocholesterolemia. W ataksji Friedreicha ważnym znaleziskiem jest podwyższony poziom glikemii, w ksantomatozie mózgowo-ścięgnistej wysokie stężenie cholestanolu, a w chorobie Refsuma podwyższony poziom kwasu fitanowego w surowicy.

Następny etap, po badaniach neuroobrazowych i laboratoryjnych, w diagnostyce różnicowej ataksji stanowi wykonanie badań dodatkowych. Badanie okulistyczne może ujawnić obecność zwyrodnienia barwnikowego siatkówki, zaćmy czy patognomicznego dla choroby Wilsona pierścienia Keisera-Fleischera.

Rozpoznanie ataksji czuciowej może zostać postawione w oparciu o wykonanie badania elektroneurograficznego-ENG. Zmiany stwierdzane w ENG wskazują na typ uszkodzenia: aksonalny, demielinizacyjny lub mieszany, co pozwala zawęzić liczbę możliwych rozpoznań.

Ostateczne potwierdzenie rozpoznania w większości ataksji przewlekłych jest możliwe w oparciu o badanie genetyczne [13].

\section{MOŻLIWOŚCI LECZENIA}

W ostrej ataksji móżdżkowej leczenie najczęściej nie jest konieczne. W zapaleniu móżdżku farmakoterapia jest uzależniona od wywołującego czynnika infekcyjnego, a przy bardzo nasilonym obrzęku stosuje się dodatkowo mannitol oraz glikokortykosteroidy. W zespole Kinsbourne'a zastosowanie ma intensywne leczenie immunosupresyjne w oparciu o kortykotropinę (wykazującą podobne działanie do sterydów, ale silniej oddziałująca na ośrodkowy układ nerwowy) w skojarzeniu z glikokortykosteroidami. 
Ponadto w niektórych sytuacjach stosuje się dożylne immunoglobuliny oraz rytuksymab (chimeryczne przeciwciało monoklonalne przeciw CD20), który jest zarezerwowany do sytuacji gdy w płynie mózgowo-rdzeniowym przeważają aktywowane limfocyty B.

$\mathrm{W}$ ataksjach napadowych genetycznie uwarunkowanych dobre efekty obserwowano po zastosowaniu acetalozamidu, a w ataksjach napadowych o podłożu metabolicznym po zastosowaniu leczenia dietetycznego (np. w niedoborze biotynidazy-suplementacja wolną biotyną przez całe życie pacjenta).

W przeciwieństwie do ataksji napadowych, dla większości ataksji przewlekłych brak jest możliwości leczenia przyczynowego, wówczas rehabilitacja pozostaje najbardziej skuteczną metodą poprawiającą jakość życia chorych. Jednak mimo to $\mathrm{w}$ ataksji $\mathrm{z}$ niedoborem witaminy E, abetalipoproteinemii potwierdzono skuteczność suplementacji witaminą E, w niedoborze transportera GLUT 1-diety ketogennej, w chorobie Niemanna-Picka typu C Miglustatu - inhibitora syntezy glikosfingolipidów, w cereidolipofuscynozie neuronalnej typu II-Cerliponazy alfa, w chorobie Refsuma - diety z eliminacją produktów zawierających kwas fitanowy (czerwone mięso, produkty mleczne), w ksantomatozie mózgowo-ścięgnistej - kwasu chenodeoksycholowego $[10,13]$.

\section{PODSUMOWANIE}

Ataksja mimo niewielkiej częstości występowania w populacji pediatrycznej stanowi problem o istotnej wadze klinicznej, wynikający najczęściej z uszkodzenia móżdżku i jego połączeń lub sznurów tylnych rdzenia kręgowego. Choć w większości przypadków ataksja ma przebieg ostry i samoograniczający, może być objawem zagrażających życiu chorób takich jak: guz mózgu czy udar lub prowadzących do niepełnosprawności chorób neurodegeneracyjnych. Ogromna różnorodność jednostek i zespołów chorobowych związanych z ataksją, mnogość objawów współistniejących oraz podobieństwa w przebiegu klinicznym komplikują proces diagnostyczny. Mimo, że w odniesieniu do większości (poza nielicznymi wyjątkami) nie dysponujemy leczeniem przyczynowym, ich podejrzenie oraz potwierdzenie badaniem genetycznym z jednej strony umożliwia ocenę rokowania, ryzyka powikłań oraz czynników prowokujących wystąpienie napadów ataksji, a z drugiej daje szansę na objęcie rodziny pacjenta poradnictwem genetycznym.

\section{PIŚMIENNICTWO}

[1] Garone G., Reale A., Vanacore N., et al.: Acute ataxia in paediatric emergency departments: a multicentre Italian study. Archives of Disease in Childhood 2019; 104: 768-774.

[2] Van der Maas N.A., Bondt P.E., de Melker H., et al.: Acute cerebellar ataxia in the Netherlands: a study on the association with vaccinations and varicella zoster infection. Vaccine, 2009; 27: 1970-1973.

[3] Levy E.I., Harris A.E., Omalu B.I. et al.: Sudden death from fulminant acute cerebellitis. Pediatr Neurosurg, 2001; 35: 24-28.

[4] Tabarki B., Thabet F.: Steroid therapy for hydrocephalus due to acute cerebellitis in a child. Arch Pediatr, 2007; 14: 1007-1009.

[5] Shkalim V., Amir J., Kornreich L. et al.: Acute cerebellitis presenting as tonsillar herniation and hydrocephalus. Pediatr Neurol, 2009; 41: 200-203.

[6] Augustyn D., Jamroz E., Sobol G.: Zespół opsoklonie-mioklonie w przebiegu neuroblastoma. Neurol Dziec, 2007; 16, 32: 65-68.

[7] Hadjivassiliou M., Grünewald R.A., Lawden M., et al.: Headache and CNS white matter abnormalities associated with gluten sensitivity. Neurology, 2001; 56: 385-388.

[8] Lionetti E., Francavilla R., Pavone P. et al.: The neurology of coeliac disease in childhood: what is the evidence? A systematic review and meta-analysis. Dev. Med. Child Neurol, 2010; 52: 700-707.

[9] Barnard R.0., Campbell M.J., McDonald W.I.: Pathological findings in a case of hypothyroidism with ataxia. J Neurol Neurosurg Psychiatr, 1971; 34: 755-776.

[10] Zawadzka M.: Ataksja i choroby móżdżku [w:] Neurologia wieku rozwojowego. Steinborn B. [red.], PZWL, Warszawa 2017.

[11] Pavone P., Pratico A., Pavone V. et al.: Ataxia in children: early recognition and clinical evaluation. Italian Journal of Pediatrics, 2017; 43 1-9.

[12] Finsterer J.: Ataxias with autosomal, X-chromosomal or maternal inheritance. Can J Neurol Sci, 2009a; 36: 409-428.

[13] Zawadzka M., Mazurkiewicz-Bełdzińska M.: Ataksja-diagnostyka i postępowanie [w:] Standardy postępowania diagnostyczno-terapeutycznego w schorzeniach układu nerwowego u dzieci i młodzieży II. Steinborn B. [red.], Bifolium, Lublin 2015. 